\title{
Candesartan Cilexetil
}

National Cancer Institute

\section{Source}

National Cancer Institute. Candesartan Cilexetil. NCI Thesaurus. Code C28903.

A synthetic, benzimidazole-derived angiotensin II receptor antagonist prodrug with antihypertensive activity. After hydrolysis of candesartan cilexetil to candesartan during gastrointestinal absorption, candesartan selectively competes with angiotensin II for the binding of the angiotensin II receptor subtype 1 (AT1) in vascular smooth muscle, blocking angiotensin II-mediated vasoconstriction and inducing vasodilatation. In addition, antagonism of AT 1 in the adrenal gland inhibits angiotensin II-stimulated aldosterone synthesis and secretion by the adrenal cortex; sodium and water excretion increase, followed by a reduction in plasma volume and blood pressure. 